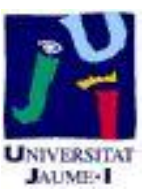

Título artículo / Títol article: Combined effect of human capital, temporary employment and organizational size on firm Performance

Autores / Autors

Vicente Roca-Puig, Inmaculada Beltrán-Martín, Mercedes Segarra Cipres

Revista:

Personnel Review, Vol. 41 No. 1, 2012, pp. 4-22.

Versión / Versió:

Pre-print

Cita bibliográfica / Cita

ROCA PUIG, Vicente, BELTRÁN MARTÍN, bibliogràfica (ISO 690): Inmaculada, SEGARRA CIPRES, Mercedes. Combined effect of human capital, temporary employment and organizational size on firm Performance. Personnel Review. 2012, Vol. 41, No 1, p. 4-22. 


\title{
COMBINED EFFECT OF HUMAN CAPITAL, TEMPORARY EMPLOYMENT AND ORGANIZATIONAL SIZE ON FIRM PERFORMANCE
}

\begin{abstract}
Purpose - This study examines how temporary employment and organizational size moderate the effect of human capital on firm performance. We also analyze the overall effect of human capital, temporary contracts and organizational size on firm performance. This enables us to identify which combination of these three variables leads to the highest levels of profitability. Design/methodology/approach - From a sample of 1,403 Spanish firms we carry out a comparative analysis of the impact of human capital on labor productivity and return on sales among small and large companies with high and low use of temporary employment.
\end{abstract}

Findings - The positive effect of human capital on return of sales is greater in large firms with low temporary employment than in small firms with high temporary employment. In addition, this positive effect is not universal because in some scenarios it is not significant. The most beneficial context is that of large companies with a high level of human capital and a low use of temporary employment.

Limitations - The results should be interpreted within the Spanish manufacturing sector.

Practical implications - Decisions about investment in human capital and the use of temporary workers should be taken jointly by personnel managers, in accordance with the size of the firm. If this holistic view is ignored, a full understanding of the impact of human capital on firm performance will be obscured. On the other hand, a common feature that large and small firms share is an incompatibility between human capital and temporary employment.

Originality/value - Growing interest has been shown in the degree to which investment in human capital contributes to firm performance; yet limited research attention has been paid to the contextual conditions that moderate this relationship. Investment in human capital can be more beneficial in some scenarios than in others. 
Keywords - Business performance, human capital, small business, temporary workers.

Paper type - Research paper. 


\section{INTRODUCTION}

A firm's human capital is an important source of sustained competitive advantage (Hitt et al., 2001) and therefore investments in the human capital of the workforce may increase employee productivity and financial results (Black and Lynch, 1996; Pfeffer, 1998; Snell and Dean, 1992). Traditional human capital theory research has focused on employees' human capital and its effect on earnings (Becker, 1964). Human capital refers to the collective knowledge, skills, and abilities of the individuals working in an organization (Snell and Dean, 1992). From an organizational perspective, human capital is the result of a firm's deliberate investment through the selective hiring of employees with high general skills (or formal education) plus a firm investment in training of more specific skills through "in-house" training activities (Lepak and Snell, 1999, 2002; Skaggs and Youndt, 2004). Firms can thus increase their human capital levels through human resource management practices related to employee selection and training. Organizations can use selection to increase their generic human capital, while focusing on training to develop firm-specific human capital (Groot and Van Den Brink, 2000; Skaggs and Youndt, 2004).

Becker and Gerhart (1996) and Youndt et al., (1996) state that the usefulness of human capital will be more important in some contexts than in others. This contingency perspective has traditionally been adopted to examine how company strategy moderates the effect of human capital on firm performance (e.g., Hitt et al., 2001; Skaggs and Youndt, 2004). Contingency studies using other organizational characteristics as moderators are needed to gain further insights into human capital-performance relationships (Youndt et al., 1996). It is our purpose to contribute to this line of research by jointly introducing two new moderator variables: organizational size and temporary employment. The human resource practices that are effective in large organizations will not automatically work in small organizations (Tansky and Heneman, 2003) and, consequently, more attention should be given to the 
interaction between organizational size and human resource management practices related to human capital (Heneman et al., 2000). Unfortunately, studies that have analyzed the impact of human capital on firm performance only considered organizational size as a control variable or took samples of either large or small firms (e.g., Hayton, 2003; Rauch et al., 2005; Skaggs and Youndt, 2004), therefore ignoring the potential influence of organizational size on the relationship between human capital and firm performance and preventing comparative studies between large and small firms. Similarly, Burges and Connell (2006) point to the paucity of literature examining the interaction between temporary work and human capital. Various authors (e.g., Auer and Cazes, 2003; Pfeffer, 1998) warn that the use of temporary contracts, a form of employment that firms increasingly resort to, can moderate the value of human capital.

In this study, we take the firm as our unit of analysis to examine how the effect of human capital investments on firm performance varies according to the use of temporary workers and the size of the organization. The objective of the study is two fold. First, we aim to observe whether this effect varies among firms with different sizes and uses of temporary contracts. Our second aim is to discover the overall effect of human capital, temporary contracts and organizational size on the level of firm performance. To this end, we identify the combination of these three variables that leads to the highest and lowest levels of profitability, using the Survey on Business Strategies carried out by the Ministry of Industry, Tourism and Trade on a sample of 1,403 Spanish industrial firms. With a few exceptions, most research on the firm-level impact of human capital has been specific to United States companies; however experience in other countries may provide information to fill the gaps in the knowledge about the United States environment (Heneman et al., 2000; Stavrou, 2005). 


\section{CONCEPTUAL FRAMEWORK}

Firms promote their human capital and therefore create value through selection and training, thus increasing their performance (Hitt et al., 2001). Considerable empirical evidence (e.g., Black and Lynch, 1996; Delaney and Huselid, 1996; Youndt et al., 1996) corroborates the positive effects of human resource practices related to enhancing human capital for firms' outcomes. There are several reasons for this. First, this combination (selection + training) provides a firm with a skilled workforce capable of ongoing learning, and employees develop a greater knowledge to respond to intense competition, constant product innovation and more complex technologies (Appelbaum et al., 2000; Batt, 2002; Snell and Dean, 1992). In this vein, generic human capital (e.g., years of schooling) is especially important because people who have received a better education have a higher potential to learn and contribute to the success of the company (Hatch and Dyer, 2004; Hitt et. al., 2001; Rauch et al., 2005). Second, as the level of employee human capital is fostered, people develop more efficient means of accomplishing task requirements, thereby increasing productivity. Black and Lynch (1996) showed that the average educational level in firms is positively related to business productivity. Third, high skills in the workforce are a requirement for empowerment, and benefit from delayering the organization (Appelbaum et al., 2000). More responsibility at shop floor level enables the firm to delayer the organization by reducing middle management. Furthermore, employee participation in decision making increases motivation and commitment to the organization and encourages employees to work harder (Huselid, 1995; Pfeffer, 1998).

Fourth, intangible resources (like human capital) are more likely to produce a competitive advantage because they are rare and socially complex, and therefore difficult to imitate (Hatch and Dyer, 2004; Hitt et al., 2001). In particular, specific human capital represents an inimitable asset in terms of knowledge and skills that are only of use to an 
individual company (Lepak and Snell, 2002; Rauch et al., 2005). Human capital theorists (e.g., Becker, 1964) suggest that firms will invest significantly to develop unique and nontransferable (i.e., firm-specific) skills through extensive training initiatives (Hatch and Dyer, 2004; Lepak and Snell, 1999). Development of human capital is often path-dependent and needs to be nurtured over time by investment in continuous training (Lepak and Snell, 1999, 2002). Fifth, the human capital pool can improve firm performance through its contribution to the firm's flexibility. In this sense, investment in human capital improves employability and therefore labor flexibility (Groot and Van Den Brink, 2000). Workers with higher levels of education and training are more employable, i.e., they can be employed in more jobs and perform multiple tasks within the firm. According to Lepak et al., (2003) one advantage of this "resource flexibility" is that it enhances the ability of the organization to deploy its workforce effectively, and thus, improve organizational performance.

Firms may also improve their performance by means of temporary employment (Matusik and Hill, 1998; Valverde et al., 2000). Temporary workers are hired to perform jobs for short periods; their employment can last anywhere from hours to months, and ends when the employing firm no longer desires their services (Davis-Blake et al., 2003). Lepak et al, (2003) argue that this contract work employment mode enhances "coordination flexibility", so that firms can efficiently adjust the number or types of skills in the firm to cope with fluctuations in product or service demands. Temporary employment offers managers greater flexibility to deal with fluctuations in customer demands by assimilating a part of their labor costs as variable rather than fixed costs (Lepak et al., 2003; Valverde et al., 2000). Furthermore, firms may increase labor productivity and reduce costs by using temporary employment to screen potential workers for regular full-time positions (Houseman, 2001). Companies may save by hiring permanent workers through temporary help agencies if these agencies enjoy economies of scale and can recruit and screen workers more cheaply. 
Temporary workers are also used as a means of accessing valuable knowledge for new services and for high quality products, which is reflected in increased revenues (Cardon, 2003; Matusik and Hill, 1998). Highly skilled professionals and technical experts in temporary employment create new and specific knowledge within the organizations that engage them; this knowledge would not otherwise be developed internally, and is especially valuable in dynamic and competitive industries.

\section{Interaction between human capital, temporary employment and organizational size}

Human resource management must be observed as a system — an integrated whole — in which the complementarities or synergies between human resource practices and other contextual factors affect firm performance (Becker and Gerhart 1996; Dyer and Reeves, 1995; Youndt et al., 1996). Consequently, an overall view of human capital must be taken, in which its interactions with other elements of the organization are included and evaluated. Studies such as those by Hayton (2003), Hitt et al., (2001) and Skaggs and Youndt (2004) indicate that the value of human resource practices related to enhancing firms' human capital depends on the context in which they are used.

There are various reasons why temporary employment reduces the effectiveness of human capital. First, Appelbaum et al. (2000), Davis-Blake et al. (2003) and Pfeffer (1998) argue that workers will only expend extra effort if they expect a high level of permanence in the job. Temporary employment breaks the traditional deal of a lifelong job with mutual loyalty between the employer and the employee (Pfeffer, 1998; Tsui and $\mathrm{Wu}, 2005)$. Where employment security exists in a firm, it helps to strengthen the relationship of trust between employees and employers, thereby increasing employee motivation and commitment to the firm. The effectiveness of even highly skilled employees will be limited if they are not motivated to perform their jobs (Delaney and Huselid, 1996, Huselid, 1995). Second, DavisBlake et al. (2003) and Sánchez and Toharia (2000) argue that the use of temporary 
employees also has a negative repercussion on the motivation and commitment of other employees that do have permanent contracts. The proportion of temporary workers negatively affects the average level of labor effort in the firm, since this kind of human resource policy affects the morale of all types of workers and breaks down group cohesion and stability of relations between workers. Third, Appelbaum et al. (2000) and Arulampalam and Booth, (1998) state that greater firm investment in training workers will be more efficient when the firm follows a policy of permanent employment contracts because the firm can amortize its investment. The target of using temporary workers is not compatible with the target of enhancing employees' ability to perform a variety of jobs through the acquisition of skills (Arulampalam and Booth, 1998). Firms are more likely to invest in training and development of employee skills, the longer the post-training period over which they can recover their investment.

Various studies have examined the issue of organizational size (e.g., Batt, 2002; Panayotopoulou et al., 2003) and suggest that the positive impact of human capital on firm performance is more pronounced in large rather than small firms. First, Sels et al. (2006) and Way (2002) argue that the cost of investment in human capital for small firms outweighs the benefits that they gain from providing high human capital, since small firms do not obtain as many benefits from economies of scale as large firms do. Human capital expenditures can be spread over the output; and therefore, large firms earn higher returns per unit of human capital practices. Second, Panayotopoulou et al. (2003) argue that in small firms, generally in the growth stage of the organizational life cycle, human resource management is mainly administrative, as the primary concern of the organization is to grow, and thus focuses on short-term economic factors. In contrast, a large firm, generally in the mature stage, has lower growth expectations, and gives more importance to effectiveness, which is achieved by gaining competitive advantage through its human resources. Therefore, organizational size is 
expected to positively affect the relationship between human capital and firm performance. Third, small firms cannot benefit from delayering the organization, as they do not employ any middle management that can be reduced by increasing employee empowerment on the shop floor (Appelbaum et al., 2000). In small firms it is also difficult to introduce self-responsible teams that exclude the hierarchical position of the entrepreneur. Fourth, if a small firm serves a local market, opportunities to increase sales through more human capital are very scarce (Batt, 2002). Investment in human capital does not pay off because the restricted scope of their markets limits sales opportunities. Hence, any focus on recruiting and developing a highly competent workforce will not have a positive effect on small firm productivity.

Additionally, organization size may be also a significant moderator of the relationship between temporary employment and firm performance. Studies such as those by Forde and Slater (2006), Mangum et al., (1985) and Ruiz-Santos et al., (2003) report that large firms have a greater propensity than smaller ones to hire temporary workers since they have more to gain from applying this contracting model. This could be due to more volatile demand for products in larger companies than in small ones, requiring the former to use more temporary employees to meet the changes in demand (Ruiz-Santos et al., 2003). Furthermore, large companies, which generally have more sophisticated human resource departments than small companies, may be better positioned to avail themselves of opportunities and advantages presented by the rapidly growing and dynamic temporary help industry (Forde and Slater, 2006; Houseman, 2001). Large firms appear to have a greater volume of temporary worker usage because they have more rationalized hiring systems and are better able to identify when temporary workers can be used efficiently (Mangum et al., 1985). Finally, Stavrou (2005) argues that large organizations can more readily cope with the increased administrative costs of adopting flexibility programs for temporary workers, and as a result the positive 
relationship between temporary employment and firm performance will be stronger in larger than in smaller firms.

In sum, the greater a firm's use of temporary workers, the lower the positive effect of human capital on its performance will be. In contrast, the larger the organization, the greater the positive effects of human capital and temporary employment on firm performance will be. If the usefulness of human capital is to be correctly evaluated we must jointly observe temporary employment and organizational size as moderating variables and, to this end, an interaction between these three variables must be introduced. This three-way interaction would signal that firm performance on human capital regression varies with differing organizational size-temporary employment joint values, or is conditional on the specific organizational size-temporary employment combination, being greater for some than others. Similarly to Hitt et al., (2001), we posit that the gestalt-overall view-of the previous arguments suggests a complex negative three-way interaction of human capital, temporary employment and organizational size in the creation of firm value. Taking human capital as the main variable, we expect that the larger the size of the organization and the lower its use of temporary contracts, the higher the positive impact of human capital on firm performance will be, such that:

Hypothesis: The positive effect of human capital on firm performance will be greater in large firms with low temporary employment than in small firms with high temporary employment.

\section{METHODOLOGY}

\section{Sample}

To empirically test the theoretical hypothesis put forward, we used the Survey on Business Strategies - Encuesta sobre Estrategias Empresariales (ESEE, 2002)—carried out 
by the Ministry of Industry, Tourism and Trade. Financed by the Spanish Ministry of Industry and Energy, the SEPI Foundation is responsible for the Survey's design and administration through the Economic Research Program. The ESEE complements the information from two essential statistical sources that have traditionally been available for analyzing Spanish industry: the Industrial Survey published by the Spanish National Statistics Institute, and the Bank of Spain's Central Balance Sheet Data Office. The survey was mailed to a contact in the firm whom the SEPI Foundation had previously agreed would respond to the survey questions. In small firms, the primary respondent is the firm's manager. The ESEE was designed so that the most knowledgeable respondent could provide those data if the main respondent was unsure about them.

The reference population for the survey comprises Spanish industrial manufacturing firms with 10 or more employees, with the exception of industrial activities related to oil refining and the treatment of fuels. All the variables measured take an annual time frame. We used data from 2002 in our study, the most recent year in which the full survey was undertaken. From the original sample of firms (1,635 firms), cases with missing data for any of the variables included in the study were eliminated (90 firms), as were cases with coding errors (125 firms) and non-standard cases (17 firms) that could devalue the information provided for that year, such as firms affected by takeover, merger or separation processes. The final sample used in this study was 1,403 firms. Distribution by sector of activity is provided in Table 1, which includes both the Standard Industrial Classification system (SIC) and the Spanish National Classification of Economic Activities-Clasificación Nacional de Actividades Económicas (CNAE). According to European Commission (1996) criteria, 671 cases $(47.8 \%)$ were small firms (10-49 employees), 377 cases $(26.9 \%)$ were medium-sized firms (50-249 employees) and 355 (25.3\%) were large firms (250 employees and over). 
Insert Table 1

\section{Measures}

Control variables. Following the advice of researchers in the field (e.g., Becker and Gerhart, 1996; Huselid, 1995), due to the large size of the dataset a conservative approach was taken to include as many control variables as possible. Specifically, we selected five control variables: age of the organization, degree of dependency, sector of activity, labor intensity and innovative intensity. The age of the firm (AGE) was calculated as the number of years between its constitution and the year of the survey. Degree of dependence (DEP) was defined as the percentage of participation in the firm's capital by another firm. The industrial sector was defined by the CNAE classification, with 13 sectors of activity identified. The labor intensity variable (LABINT) was calculated as the ratio between the personnel costs and the total net fixed assets. Finally, innovative propensity (INNOV) was calculated as the percentage coefficient between R\&D expenditure and firm sales.

Independent variables. Human capital is the result of a firm's deliberate investment through the selective hiring of employees with high general skills plus a firm investment in training of more specific skills (Hatch and Dyer, 2004; Snell and Dean, 1992). Similarly to Skaggs and Youndt (2004), we used a composite selection and training index to assess the firms' human capital. More specifically, we measured investment in human capital (HC) as the mean of the standardized scores of two indicators: the educational level of the hired employees, calculated as the workers with higher or intermediate education as a proportion of the total workforce; and investment in training, calculated as the ratio between training expenditure and the total number of employees in the firm. In sum, our measure of human capital had two dimensions, formal education quality (a proxy for general skills) and 
investment in training (a proxy for specific skills). With regard to the two moderating variables, organizational size (SI) was defined by the total number of employees in the firm, while temporary employment (TE) was calculated as the proportion of the total workforce of employees with a temporary contract.

Dependent variables. We used organizational and financial measures of firm performance because they represent different hierarchical levels and because human capital is most likely to directly impact on organizational outcomes, followed by financial outcomes (Dyer and Reeves, 1995). In comparison with organizational outcomes, the increasing complexity of factors that influence financial outcomes would modify the contribution of human capital (Dyer and Reeves, 1995, Huselid, 1995). Concerning organizational performance, we followed previous studies (e.g., Koch and McGrath, 1996), by choosing the logarithm of sales per employee as a measure of labor productivity (PROD). Concerning financial performance, we followed Hitt et al. (2001), choosing return on sales (ROS) to detect operational efficiency.

Table 2 presents the sets of control, independent and dependent variables and their respective descriptive statistics. Of note is the high level of temporary contracts in the sample of firms analyzed, with an average of 16\%. In Spain, following the labor reform of 1984 introduced to bring down high rates of unemployment, widespread use of temporary contracts was observed in almost all sectors of the economy and types of jobs (Diaz-Mayans and Sánchez, 2004). Table 3 presents the correlation coefficients among the variables. In contrast to expectations, the existence of a negative relation $(-0.073)$ between organizational size and temporary contracts reveals the use of temporary contracts to be more widespread in small than in large firms. As in Davis-Blaque and Uzzi (1993), large firms were found to be less likely than small firms to use temporary workers. In the Spanish context, this may be because only large firms have their own collective agreements, while small firms are bound by 
sectoral agreements negotiated at a national level that cannot take into account the characteristics and specific situation of small firms concerning their need for greater flexibility. Likewise, the positive correlation $(0.221)$ between organizational size and human capital demonstrates that small firms have a significantly lower level of human capital than large firms. Due to financial limitations, small firms are less likely than large firms to invest in human capital (Hayton, 2003).

Insert Table 2

Insert Table 3

\section{RESULTS}

We follow the recommendations of Aiken and West (1991) to carry out the analysis of the interaction between human capital, temporary employment and organizational size. Previous human resource research examining an interaction between three variables has adopted this procedure (e.g., Hitt et al., 2001). These authors recommend centering the independent variables and then using these centered values to calculate the interactions between the variables. They also advise following the hierarchical regression procedure, such that when the existence of a third order interaction is postulated, the principal effects and the second order interaction effects must first be introduced. Table 4 shows the results of the regression analysis carried out for the two firm performance indicators. We then calculate the simple regression lines of human capital (principal variable) on firm performance (dependent variable), according to organizational size and temporary employment (moderator variables). This involves dichotomizing the two moderator variables by choosing a standard deviation 
above (high) and below (low) the corresponding mean values of temporary employment and organizational size. The possible combinations between these two levels for each of the two dimensions provide us with the four scenarios shown in Figure 1. The results of this analysis are provided in Table 5.

Insert Figure 1

Finally, Table 6 shows the values of the $t$ statistic of differences between the various scenarios. Specifically, to test the proposed hypothesis, a comparative analysis must be made between the contexts of small firms with high temporary employment (B) and large firms with low temporary employment $(\mathrm{C})$. The hypothesis will be confirmed if the impact of human capital on firm performance is positive and greater in context $\mathrm{C}$ than in context $\mathrm{B}$. As evidenced in Table 5, this first requirement is fulfilled for both labor productivity and ROS. If there is a significant difference between the values of the regression coefficients of the two different contexts, the condition is sufficiently met. The second condition (see Table 6) is met when return on sales is examined (3.317), but not in the case of labor productivity. Human capital has a similar significant positive impact in these two contexts. Consequently, our hypothesis is only confirmed when ROS is examined..$^{(1)}$

Insert Table 4

Insert Table 5 
Insert Table 6

\section{DISCUSSION}

Although the hypothesis formulated in this study focuses on the comparison of two opposed contexts (B-C), we also considered it worthwhile to adopt a descriptive approach and highlight certain results from Tables 5 and 6 . In general, the existence of significant differences in the effect of human capital on firm performance between small and large firms with high and low use of temporary employment confirms that organizational size and temporary contracts act as moderating variables. These results support the thesis put forward by Becker and Gerhart (1996) and Youndt et al. (1996) concerning the need to adopt an integral view of human resource management in search of complementarities. In particular, we demonstrate that the positive effect of human capital on firm performance is not universal; in other words, an increase in human capital does not always have a positive effect on firm performance. Specifically, the results show that human capital has a negative effect on ROS in large firms with high temporary employment.

The second objective of the present study, to identify the most and the least beneficial combinations of the three variables, is observed from a graphic representation of the simple regression lines (Figures 2 and 3). The firm performance values shown in these figures were calculated from the higher and lower values of human capital, defined respectively by a standard deviation above (0.793) and below (-0.793) its mean value (see Table 2). Figure 2 shows that the combination with the optimum labor productivity (11.793) occurs when a large firm follows a human resource management policy based on low levels of temporary contracts and high human capital. In contrast, the least beneficial context (11.072) occurs in the small firms with a low level of human capital and a high use of temporary employment. In 
Figure 3, we observe that the combination with the optimum profitability $(0.238)$ occurs when a large firm follows a human resource management policy based on low levels of temporary contracts and high human capital. In contrast, the least beneficial context (0.033) occurs in small companies with a high degree of human capital and a high use of temporary employment. Finally, it should be noted that the most beneficial context, in both labor productivity and ROS, occurs in large companies with a high degree of human capital and a low use of temporary employment.

Insert Figure 2

Insert Figure 3

Our results also contribute to the current debate surrounding the duality between internal and external employment modes (Boselie et al., 2009; Davis-Blaque and Uzzi, 1993; Lepak and Snell, 2002). Are the two employment modes compatible? Firms can internalize employment and build their employee skill base through significant investment in training and education to develop and cultivate the knowledge, skills and abilities of their employees within their firm (Lepak et al., 2003). On the other hand, firms can externalize employment by hiring temporary workers. Although previous research has examined this controversial issue (e.g., Bacon and Blyton, 2001; Lepak et al., 2003, Tsui and Wu, 2005), our study allows this compatibility to be examined in small and large firms. As shown in Tables 5 and 6 , the effect of human capital on performance is more positive in an organizational context of low temporary employment in both small (A vs. B) and large companies (C vs. D), with significant differences in small companies for labor productivity $(t=1.760)$ and in large 
companies for ROS ( $t=4.754)$. In addition, Figures 2 and 3 reveal that firm performance is higher when low temporary employment is combined with high human capital, compared with a high temporary employment-high human capital combination in both small and large firms. Taken together, all this empirical evidence appears to tip the balance towards the hypothesis of incompatibility between external and internal employment modes, in both small and large firm contexts.

\section{Supplemental analysis}

In line with the posited hypothesis, human capital was chosen as the main variable in previous analyses. Alternatively, given that an interaction is symmetrical (Aiken and West, 1991), we can also interpret the results in terms of temporary employment, by now considering human capital and organizational size as moderating variables (see Table 7). This coincides with empirical studies aimed at delimiting the effect of temporary employment on firm performance (e.g., Cardon, 2003; Davis-Blake et al, 2003; Matusik and Hill, 1998) and with the call from Lepak et al., (2003) and Ruiz-Santos and Ruiz-Mercader (2003) for more research to explore the relationship between temporary employment and firm performance in different scenarios.

If we consider temporary employment as the main variable, the equivalent hypothesis is that the positive effect of temporary employment on firm performance will be greater in large firms with low human capital than in small firms with high human capital levels. Clearly, as in the previous case, this hypothesis is confirmed when we examine the ROS $(0.252>-$ 0.086 ; $t=3.41$ ), but not when we select labor productivity. Similarly, results show a positive relation between temporary employment and ROS only in large firms with low human capital levels. The effect is negative in all other contexts, and particularly significant in the case of

small firms with a high level of human capital over labor productivity (-0.862). Previous empirical studies carried out in Spain (e.g., Diaz-Mayans and Sánchez, 2004; Sánchez and 
Toharia, 2000) also find a negative relation between temporary employment and firm performance and identify two underlying causes for this result. First, there is some evidence to suggest that employers' use of temporary employment is due to pressures on labor costs. Forde and Slater (2006) and Houseman (2001) report that although few employers said they used temporary employment in order to save on labor costs (wage, pension, health insurance other social expenditures), employers primarily do make savings by using these arrangements. It therefore comes as no surprise that most temporary employees contracted by Spanish firms typically earn low wages, have a low educational level, work in precarious conditions, and that temporary employment is not used to screen for movement into permanent employment (Amuedo-Dorantes, 2001; Diaz-Mayans and Sánchez, 2004). These characteristics make it difficult to capitalize on the advantages of using temporary employment foreseen by Houseman (2001) and Matusik and Hill (1998). Second, the high rates of temporary employment in the Spanish labor market, approximately twice the European average (Auer and Cazes, 2003), aggravate this situation. Organizations may incur considerable costs through extensive utilization of temporary contracts (Forde and Slater, 2006; Sánchez and Toharia, 2000).

\section{Insert Table 7}

\section{CONCLUSION}

We examined the combined effect of human capital, temporary employment and organizational size on firm performance. We recommend that decisions about investment in human capital and the use of temporary contracts should be taken jointly by personnel managers, in accordance with the size of the firm. If this holistic view is ignored, a full understanding of their impact on firm performance will be obscured. Given the importance of 
these interactions, isolated actions designed to achieve a certain effect may be counterproductive. In particular, our hypothesis advocates that the positive effect of human capital on firm performance is more intense in large firms with low temporary employment than in small firms with high temporary employment. Our findings partially support our contingent hypothesis, which is confirmed when ROS is examined, but not when labor productivity is selected as the dependent variable. As Dyer and Reeves (1995), Huselid (1995) and Sels et al. (2006) have previously pointed out, it is likely that these results differ because of the varying nature of these two performance indicators. While labor productivity reflects employee efforts that are somewhat insulated from variation in capital and product markets, ROS actually picks up these other factors. The mixed results could also be a sign that costs rise faster than revenues in small firms, thereby marginalizing the impact of human capital on financial performance (Sels et al., 2006).

These theoretical results have important practical implications for business management. While not wishing to minimize the differences between small and large firms, a feature common to both types of firm should be pointed out: the most profitable human resource management policy is manifest when temporary contracting is low and human capital is high. This combination leads to the highest level of labor productivity and ROS in both small and large firms. Consequently, the argument put forward by Pfeffer (1998) and Tsui and $\mathrm{Wu}(2005)$ is as relevant to small and medium firms as it is to large firms: namely that the economic value of using temporary employees is less attractive than previously perceived. The widespread use of temporary contracts has led to the situation in which many human resource managers are seeking to develop high human capital in a climate of high job insecurity. As Bacon and Blyton (2001) suggest, what is less likely, however, is that investment in human capital will achieve its full potential in the presence of high job 
insecurity. There is therefore an incompatibility between human capital investments and temporary employment.

Our findings do not coincide with Cardon's (2003) proposal that in small firms the integration of temporary workers may result in benefits, since these skilled workers represent a variable rather than a fixed cost and the financial constraints of small firms prevent them from introducing and taking advantage of high human capital. This may be because this author bases her argument on the idea that temporary employees are highly qualified, which contrasts starkly with the European and Spanish employment situation, characterized by the fact that the proportion of employees with temporary contracts is highest at the lowest education level (Diaz-Mayans and Sánchez, 2004). Moreover, as Hayton (2003) explains, for smaller firms financial constraints may mean that the implementation of human resource practices related to human capital may be limited; however, this does not mean that these practices will be less significant to firm success, and vice versa. In other words, a positive correlation between organizational size and human capital does not imply that small firms will benefit less from this investment than large firms. Likewise, although large firms are less likely than small firms to use temporary workers (Davis-Blaque and Uzzi, 1993), this should not encourage us to defend their greater use in small firms. The present study shows that temporary employment is more widespread in small than large firms, but notably, only large firms with low levels of human capital seem to benefit from using this model.

These conclusions must be appraised in light of the study's limitations. Our level of analysis is the firm and we measure human capital with proxy indicators included in the ESEE. Similarly to Hatch and Dyer (2004), Snell and Dean (1992) and Skaggs and Youndt (2004), we understand that human capital is the result of a firm's making a deliberate investment via human resource practices. Quantifying investments in human capital is useful in that it allows investors and other outside actors to analyze and understand the return of 
these investments, about which they often have only poor information (d'Arcimoles, 1997). However, from this outsider's perspective, employees' collective knowledge and skills are particularly difficult to assess and "proxies" are generally needed to evaluate them. More direct measures of employees' skills and knowledge (at an employee level of analysis) would provide a more detailed analysis of the human capital in the firm (Rauch et al., 2005). Because the ESEE survey only contains variables at the organizational level, it is not possible this type of analysis. Secondly, our results should be interpreted within the industrial context. Previous studies (e.g., Black and Lynch, 1996) have shown that the effect of human capital investments on performance may vary between manufacturing and non-manufacturing sectors. For this reason, we recommend that similar studies be carried out in other sectors of activity to test our findings. Likewise, the peculiarities of the temporary employment model in the Spanish labor context limit our results to this particular sphere; future research is therefore needed in other geographical regions.

\section{Notes}

(I) When labor productivity is selected as the dependent variable, the three-way interaction is not significant; nonetheless, we retain this interaction term in the subsequent analyses (tables 5-7 and figure 2) in line with the theoretical arguments put forward in the conceptual framework. Aiken and West (1991) recommend that if there are strong theoretical grounds for expecting an interaction, the interaction, even if non-significant, should be retained in the final regression equation.

\section{Acknowledgements}

This work was carried out as a part of a research project (ref. ECO2008-01674) funded by the Ministerio de Ciencia e Innovación. It was also supported by Bancaixa Foundation (ref. P1.1A2008-06; ref. P1.1B2008-60). 


\section{REFERENCES}

Aiken, L.S., and West, S.G. (1991). Multiple Regression: Testing and Interpreting Interactions. Newbury Park: Sage Publications.

Amuedo-Dorantes, C. (2001). "From “temp-to-perm": Promoting permanent employment in Spain," International Journal of Manpower, 22, 625-647.

Appelbaum, E., Bailey, T. Berg, P. and Kalleberg, A. (2000). Manufacturing advantage: why high-performance work systems pay off. Ithaca: Cornell University Press.

Arulampalam, W., and Booth, A. (1998). "Training and labour market flexibility: is there a trade-off?," British Journal of Industrial Relations, 36, 521-536.

Auer, P. and Cazes, S. (eds.) (2003). Employment stability in an age of flexibility. Evidence from the industrialized countries. Geneva: International Labour Office.

Bacon, N., and Blyton, P. (2001). "High involvement work systems and job insecurity in the international iron steel industry," Canadian Journal of Administrative Sciences, 18(1), $5-16$.

Batt, R. (2002). "Managing customer services: human resource practices, quit rates, and sales growth," Academy of Management Journal, 45, 587-597.

Becker, B.E., and Gerhart, B. (1996). "The impact of human resource management on organizational performance: progress and prospects," Academy of Management Journal, 39, 779-801.

Becker, G.S. (1964). Human capital. New York: Columbia University Press.

Black, S.E. and Lynch, L.M. (1996). "Human-capital investments and productivity," American Economic Review, 86(2), 263-267.

Boselie, P., Brewster, C., and Paauwe, J. (2009). "In search of balance -managing the dualities of HRM: an overview of the issues," Personnel Review, 38, 461-471. 
Burges, J., and Connell, J. (2006). “Temporary work and human resources management: issues, challenges and responses," Personnel Review, 35, 129-140.

Cardon, M.S. (2003). "Contingent labor as an enabler of entrepreneurial growth," Human Resource Management, 42(4), 357-373.

d'Arcimoles, C. (1997). "Human resource policies and company performance: A quantitative approach using longitudinal data," Organization Studies, 18, 857-874.

Davis-Blake, A., and Uzzi, B. (1993). "Determinants of employment externalization: A study of temporary workers and independent contractors," Administrative Science Quarterly, $38,195-223$

Davis-Blake, A., Broschak, J.P. and George, E. (2003). "Happy together? How using nonstandard workers affects exit, voice, and loyalty among standard employees," Academy of Management Journal, 46, 475-485.

Delaney, J.T., and Huselid, M.A. (1996). "The impact of human resource management practices on perceptions of organizational performance," Academy of Management Journal, 39, 949-969.

Diaz-Mayans, M.A., and Sánchez, R. (2004). "Temporary employment and technical efficiency in Spain," International Journal of Manpower, 25, 181-194.

Dyer, L., and Reeves, T. (1995). "Human resource strategies and firm performance: What do we know and where do we need to go?," International Journal of Human Resource Management, 6, 656-670.

ESEE. (2002). Survey on Business Strategies. SEPI Foundation. For more information, consult the website: http://www.funep.es/esee/en/einfo_que_es.asp.

European Commission. (1996). Recommendation 96/280/CE on SME Definition. CEU Journal, L. 107/8, 0004-0009. 
Forde, C., and Slater, G. (2006). "The nature and experience of agency working in Britain. What are the challenges for human resource management?" Personnel Review, 35, $141-157$.

Groot, W., and Van Den Brink, H.M. (2000). "Education, training and employability," Applied Economics, 32, 573-581.

Hatch, N.W., and Dyer, J.H. (2004). "Human capital and learning as a source of sustainable competitive advantage," Strategic Management Journal, 25, 1155-1178.

Hayton, J.C. (2003). "Strategic human capital management in SMEs: and empirical study of entrepreneurial performance," Human Resource Management, 42, 375-391.

Heneman, R.L., Tansky, J.W. and Camp, S.M. (2000). "Human resource management practices in small and Medium-Sized enterprises: unanswered questions and future research," Entrepreneurship Theory and Practice, 25, 1-11.

Hitt, M.A., Bierman, L. Shimizu, K. and Kochhar, R. (2001). "Direct and moderating effects of human capital on strategy and performance in professional service firms: a resource-based perspective," Academy of Management Journal, 44, 13-28.

Houseman, S.N. (2001). "Why employers use flexible staffing arrangements: evidence from an establishment survey," Industrial and Labor Relations Review, 55, 149-170.

Huselid, M.A. (1995). “The impact of human resource management practices on turnover, productivity, and corporate financial performance," Academy of Management Journal, $38,635-672$.

Koch, M.J., and McGrath, R.G. (1996). "Improving labor productivity: human resource management policies do matter," Strategic Management Journal, 17, 335-354.

Lepak, D.P., and Snell, S.A. (1999). "The human resource architecture: toward a theory of human capital allocation and development," Academy of Management Review, 24, 3148. 
Lepak, D.P., and Snell, S.A. (2002). "Examining the human resource architecture: The relationships among human capital, employment, and human resource configurations," Journal of Management, 28, 517-543.

Lepak, D.P., Takeuchi, R., and Snell, S.A. (2003). "Employment flexibility and firm performance: examining the interaction effects of employment mode, environmental dynamism, and technological intensity," Journal of Management, 29, 681-703.

Mangum, G., Mayall, D., and Nelson, L. (1985). "The temporary help industry: a response to the dual internal labor market," Industrial and Labor Relations Review, 38, 599-611.

Matusik, S.F., and Hill, C.W.L. (1998). "The utilization of contingent work, knowledge creation, and competitive advantage," Academy of Management Review, 23, 680-697.

Panayotopoulou, L., Bourantas, D. and Papalexandris, N. (2003). "Strategic human resource management and its effects on firm performance: an implementation of the competing values framework," International Journal of Human Resource Management, 14, 680699.

Pfeffer, J. (1998). The human equation: Building profits by putting people first. Boston: Harvard Business School Press.

Rauch, A., Frese, M., and Utsch, A. (2005). "Effects of human capital and long-term human resources development and utilization on employment growth of small-scale business: a causal analysis," Entrepreneurship Theory and Practice, 30, 681-698.

Ruiz-Santos, C., Ruiz-Mercader, J., and McDonald, F. (2003) "The use of contractual working time flexibility by Spanish SMEs," Personnel Review, 32, 164-186.

Sánchez, R., and Toharia, L. (2000). "Temporary workers and productivity: the case of Spain," Applied Economics, 32, 583-591. 
Sels, L. De Winne, S. Maes, J. Delmotte, J. Faems, D. and Forrier, A. (2006). "Unravelling the HRM-Performance link: Value-Creating and cost-increasing effects of small business HRM," Journal of Management Studies, 43, 319-342.

Skaggs, B., and Youndt, M. (2004). "Strategic positioning, human capital, and performance in service organizations: a customer interaction approach," Strategic Management Journal, 25, 85-99.

Snell, S.A., and Dean, J.W. (1992). "Integrated manufacturing and human resource management: a human capital perspective," Academy of Management Journal, 35, 467-504.

Stavrou, E.T. (2005). "Flexible work bundles and organizational competitiveness: a cross national study of the European work context," Journal of Organizational Behavior, 26, 923-947.

Tansky, J.W., and Heneman, R. (2003). “Guest editor's note: Introduction to the special issue on human resource management in SMEs: a call for more research," Human Resource Management, 42, 299-302.

Tsui, A.S., and Wu, J.B. (2005). "The new employment relationship versus the mutual investment approach: Implications for human resource management," Human Resource Management, 44, 115-121.

Valverde, M., Tregaskis, O., and Brewster, C. (2000). "Labor flexibility and firm performance," International Advances in Economic Research, 6, 649-661.

Way, S.A. (2002). "High performance work systems and intermediate indicators of firm performance within the US small business sector," Journal of Management, 28, 765785. 
Youndt, M.A., Snell, S.A. Dean, J.W. and Lepak, D.P. (1996). "Human resource management, manufacturing strategy, and firm performance," Academy of Management Journal, 39, 836-866. 
Table 1. Distribution of firms according to sectors of activity $(N=1,403)$

\begin{tabular}{llcc}
\hline SIC & CNAE & Number & Percentage \\
\hline 20 and 21 & DA. Food, drink and tobacco industry & 187 & 13.33 \\
22 and 23 & DB. Textile and clothing industry & 133 & 9.48 \\
31 & DC. Leather and footwear industry & 37 & 2.64 \\
24 and 25 & DD. Timber and cork industry & 51 & 3.64 \\
26 and 27 & DE. Paper industry; publishing, graphic arts and reproduction of engravings & 119 & 8.48 \\
28 & DG. Chemical industry & 81 & 5.77 \\
30 & DH. Rubber transformation and plastic materials industry & 85 & 6.06 \\
32 & DI. Other mineral, non-metallic product industries & 101 & 7.20 \\
33 and 34 & DJ. Primary metal industry and fabricated metal products & 216 & 15.40 \\
35 and 36 & DK. Machinery and electrical equipment manufacturing industry & 106 & 7.56 \\
38 & DL. Electrical, electronic and optical materials and equipment industry & 100 & 7.13 \\
37 & DM. Manufacturing of transportation equipment & 88 & 6.27 \\
39 & DN. Miscellaneous manufacturing industries & 99 & 7.06 \\
\hline
\end{tabular}


Table 2. Definition and descriptive statistics of the variables included in the regression analysis $(N=1,403)$

\begin{tabular}{|c|c|c|c|}
\hline Variable & Definition & Mean & s.d. \\
\hline AGE & Number of years since the firm was constituted & 24.583 & 20.734 \\
\hline DEP & Percentage of participation in the firm's capital by another firm & 34.627 & 44.668 \\
\hline DA & 1 if food, drink and tobacco industry; 0 otherwise & 0.133 & 0.340 \\
\hline DB & 1 if textile and clothing industry; 0 otherwise & 0.094 & 0.293 \\
\hline DC & 1 if leather and footwear industry; 0 otherwise & 0.026 & 0.160 \\
\hline DD & 1 if timber and cork industry; 0 otherwise & 0.036 & 0.187 \\
\hline $\mathrm{DE}$ & 1 if paper industry; publishing, graphic arts and reproduction of engravings; 0 otherwise & 0.084 & 0.278 \\
\hline DG & 1 if chemical industry; 0 otherwise & 0.057 & 0.233 \\
\hline $\mathrm{DH}$ & 1 if rubber transformation and plastic materials industry; 0 otherwise & 0.060 & 0.238 \\
\hline DI & 1 if other mineral, non-metallic product industries; 0 otherwise & 0.072 & 0.258 \\
\hline DK & 1 if machinery and electrical equipment manufacturing industry; 0 otherwise & 0.075 & 0.264 \\
\hline DL & 1 if electrical, electronic and optical materials and equipment industry; 0 otherwise & 0.071 & 0.257 \\
\hline $\mathrm{DM}$ & 1 if manufacturing of transportation equipment; 0 otherwise & 0.062 & 0.242 \\
\hline $\mathrm{DN}$ & 1 if miscellaneous manufacturing industries; 0 otherwise & 0.070 & 0.256 \\
\hline LABINT & Labor intensity & 4.888 & 58.788 \\
\hline INNOV & Innovative intensity & 0.599 & 1.661 \\
\hline $\mathrm{HC}$ & Human capital & 0.000 & 0.793 \\
\hline TE & Proportion of workers with temporary contracts & 0.160 & 0.199 \\
\hline SI & Number of employees & 200.939 & 355.288 \\
\hline PROD & Labor productivity & 1.470 & 0.591 \\
\hline ROS & Return on sales & 0.122 & 0.186 \\
\hline
\end{tabular}


Table 3. Bivariate correlations among variables ${ }^{\mathrm{a}}$

\begin{tabular}{|c|c|c|c|c|c|c|c|c|c|}
\hline Variables & 1 & 2 & 3 & 4 & 5 & 6 & 7 & 8 & 9 \\
\hline 1. AGE & 1 & & & & & & & & \\
\hline 2. DEP & $0.226^{* *}$ & 1 & & & & & & & \\
\hline 3. LABINT & -0.024 & -0.022 & 1 & & & & & & \\
\hline 4. INNOV & $0.107^{* *}$ & $0.129^{* *}$ & 0.024 & 1 & & & & & \\
\hline 5. $\mathrm{HC}$ & $0.218^{* *}$ & $0.327^{* *}$ & -0.002 & $0.224^{* *}$ & 1 & & & & \\
\hline 6. TE & $-0.234^{* *}$ & $-0.204^{* *}$ & -0.021 & $-0.097^{* *}$ & $-0.145^{* *}$ & 1 & & & \\
\hline 7. SI & $0.267^{* *}$ & $0.371^{* *}$ & -0.019 & $0.060^{*}$ & $0.221^{* *}$ & $-0.073^{* *}$ & 1 & & \\
\hline 8. PROD & $0.268^{* *}$ & $0.475^{* *}$ & -0.020 & $0.069^{*}$ & $0.388^{* *}$ & $-0.238^{* *}$ & $0.305^{* *}$ & 1 & \\
\hline 9. ROS & $0.139^{* *}$ & $0.228^{* *}$ & -0.022 & -0.005 & $0.188^{* *}$ & -0.039 & $0.451^{* * *}$ & $0.385^{* *}$ & 1 \\
\hline
\end{tabular}

Notes: ${ }^{a}$ Dichotomous variables of the industrial sectors were omitted. $\quad * * p<0.01 ; * p<0.05$; (two-tailed) 
Table 4. Results of the hierarchical regression analysis

\begin{tabular}{|c|c|c|c|c|c|c|}
\hline \multirow[t]{2}{*}{ Variables } & \multicolumn{3}{|c|}{ Labor productivity } & \multicolumn{3}{|c|}{ Return on sales } \\
\hline & Model 1 & Model 2 & Model 3 & Model 1 & Model 2 & Model 3 \\
\hline AGE & $0.084^{* * *}$ & $0.086^{* *}$ & $0.086^{* * *}$ & -0.001 & -0.003 & -0.005 \\
\hline DEP & $0.304^{* *}$ & $0.289^{* *}$ & $0.289^{* *}$ & 0.040 & 0.042 & 0.041 \\
\hline DA & $0.080^{* *}$ & $0.079^{* *}$ & $0.079^{* *}$ & 0.006 & 0.003 & 0.001 \\
\hline DB & $-0.192^{* *}$ & $-0.191^{* *}$ & $-0.191^{* *}$ & -0.041 & -0.044 & -0.043 \\
\hline DC & -0.021 & -0.019 & -0.019 & -0.017 & -0.019 & -0.019 \\
\hline $\mathrm{DD}$ & -0.001 & 0.000 & 0.000 & -0.034 & -0.034 & -0.035 \\
\hline $\mathrm{DE}$ & -0.011 & -0.010 & -0.010 & 0.013 & 0.011 & 0.011 \\
\hline DG & $0.057^{*}$ & $0.061^{*}$ & $0.061^{*}$ & $0.058^{*}$ & 0.045 & 0.039 \\
\hline DH & -0.021 & -0.018 & -0.018 & 0.024 & 0.026 & 0.025 \\
\hline DI & -0.027 & -0.027 & -0.027 & 0.020 & 0.022 & 0.023 \\
\hline DK & $-0.049+$ & $-0.049+$ & $-0.049^{*}$ & 0.010 & 0.010 & 0.014 \\
\hline DL & $-0.052^{*}$ & $-0.051^{*}$ & $-0.051^{*}$ & 0.014 & 0.016 & 0.015 \\
\hline $\mathrm{DM}$ & -0.003 & -0.001 & -0.001 & -0.004 & -0.001 & 0.003 \\
\hline $\mathrm{DN}$ & $-0.090^{* *}$ & $-0.087^{* *}$ & $-0.087^{* *}$ & -0.020 & -0.020 & -0.019 \\
\hline LABINT & -0.013 & -0.013 & -0.013 & -0.015 & -0.015 & -0.014 \\
\hline INNOV & -0.034 & $-0.040+$ & $-0.040+$ & $-0.061^{*}$ & $-0.062^{*}$ & $-0.062^{*}$ \\
\hline $\mathrm{HC}$ & $0.192^{* *}$ & $0.194^{* *}$ & $0.195^{* *}$ & $0.069^{*}$ & $0.047+$ & 0.036 \\
\hline $\mathrm{TE}$ & $-0.126^{* *}$ & $-0.143^{* *}$ & $-0.144^{* *}$ & 0.014 & -0.019 & -0.012 \\
\hline SI & $0.094^{* *}$ & $0.131^{* *}$ & $0.132^{* *}$ & $0.415^{* *}$ & $0.401^{* *}$ & $0.393^{* *}$ \\
\hline HCxTE & & $-0.049^{*}$ & $-0.048+$ & & $-0.095^{* *}$ & $-0.115^{* *}$ \\
\hline $\mathrm{HCxSI}$ & & $-0.076^{* *}$ & $-0.074^{* *}$ & & 0.027 & -0.002 \\
\hline TExSI & & 0.008 & 0.008 & & 0.018 & 0.026 \\
\hline HCXTEXSI & & & 0.004 & & & $-0.072^{*}$ \\
\hline$R^{2} ; F$ & $0.381 ; 44.74^{* *}$ & $0.386 ; 39.48^{* *}$ & $0.386 ; 37.74^{* *}$ & $0.224 ; 21.01^{* *}$ & $0.232 ; 18.93^{* *}$ & $0.235 ; 18.41^{* * *}$ \\
\hline
\end{tabular}

Notes: Standardized regression coefficients. $* * p<0.01 ; * p<0.05 ;+p<0.10$ (two-tailed) 
Table 5. Effect of human capital $(X)$ on firm performance $(Y)$ according to organizational size and temporary employment

\begin{tabular}{|c|l|c|c|c|}
\hline \multirow{2}{*}{$\begin{array}{c}\text { Labor } \\
\text { productivity }\end{array}$} & \multicolumn{3}{|c|}{ Organizational size } \\
\cline { 2 - 5 } & Low & High \\
\hline \multirow{2}{*}{$\begin{array}{c}\text { Temporary } \\
\text { employment }\end{array}$} & High & $B: Y=11.217+0.183^{* *} X(0.056)$ & $D: Y=11.437+0.079 X \quad(0.075)$ \\
\cline { 2 - 5 } Return on sales & $A: Y=11.456+0.314^{* *} X(0.049)$ & $C: Y=11.644+0.188^{* *} X(0.051)$ \\
\cline { 2 - 5 } & \multicolumn{2}{|c|}{ Organizational size } \\
\hline \multirow{2}{*}{$\begin{array}{c}\text { Temporary } \\
\text { employment }\end{array}$} & High & $B: Y=0.035-0.002 X$ & $(0.015)$ & $D: Y=0.194-0.050^{*} X \quad(0.020)$ \\
\cline { 2 - 5 } & Low & $A: Y=0.052+0.020 X$ & $(0.013)$ & $C: Y=0.186+0.066^{* *} X \quad(0.014)$ \\
\hline
\end{tabular}

Notes: standard error in parenthesis. $* * p<0.01 ; * p<0.05$; (two-tailed)

Table 6. Values of the $t$ statistic between each pair of simple regression lines

\begin{tabular}{l|cccccc}
\hline Simple lines & $A-B$ & $A-C$ & $A-D$ & $B-C$ & $B-D$ & $C-D$ \\
\hline Labor productivity & $1.760+$ & $1.800+$ & $2.640^{* * *}$ & 0.066 & 1.111 & 1.203 \\
\hline ROS & 1.157 & $2.421^{* *}$ & $2.941^{* * 3}$ & $3.317^{* * \%}$ & $1.920+$ & $4.754^{* * \%}$ \\
\hline
\end{tabular}

Notes: $* * p<0.01 ; * p<0.05 ;+p<0.10$ (two-tailed)

Table 7. Effect of temporary employment $(X)$ on firm performance $(Y)$ according to organizational size and human capital

\begin{tabular}{|c|c|c|c|}
\hline \multirow{2}{*}{\multicolumn{2}{|c|}{$\begin{array}{c}\text { Labor } \\
\text { productivity }\end{array}$}} & \multicolumn{2}{|c|}{ Organizational size } \\
\hline & & \multirow{2}{*}{$\begin{array}{c}\text { Low } \\
Y=11.553-0.862^{* *} X(0.234)\end{array}$} & High \\
\hline \multirow{2}{*}{$\begin{array}{l}\text { Human } \\
\text { capital }\end{array}$} & High & & $Y=11.646-0.737^{* *} X(0.273)$ \\
\hline & Low & $Y=11.139-0.339^{+} X(0.184)$ & $Y=11.435-0.302 X(0.287)$ \\
\hline \multirow{2}{*}{\multicolumn{2}{|c|}{ Return on sales }} & \multicolumn{2}{|c|}{ Organizational size } \\
\hline & & Low & High \\
\hline \multirow{2}{*}{$\begin{array}{l}\text { Human } \\
\text { capital }\end{array}$} & High & $Y=0.051-0.086 X \quad(0.063)$ & $Y=0.197-0.211^{* * *} X(0.073)$ \\
\hline & Low & $Y=0.037-0.001 X \quad(0.049)$ & $Y=0.184+0.252^{* * *} X \quad(0.077)$ \\
\hline
\end{tabular}

Notes: standard error in parenthesis. ${ }^{* *} p<0.01 ; * p<0.05 ;+p<0.10$ (two-tailed) 
Figure 1. Types of possible contingent scenarios

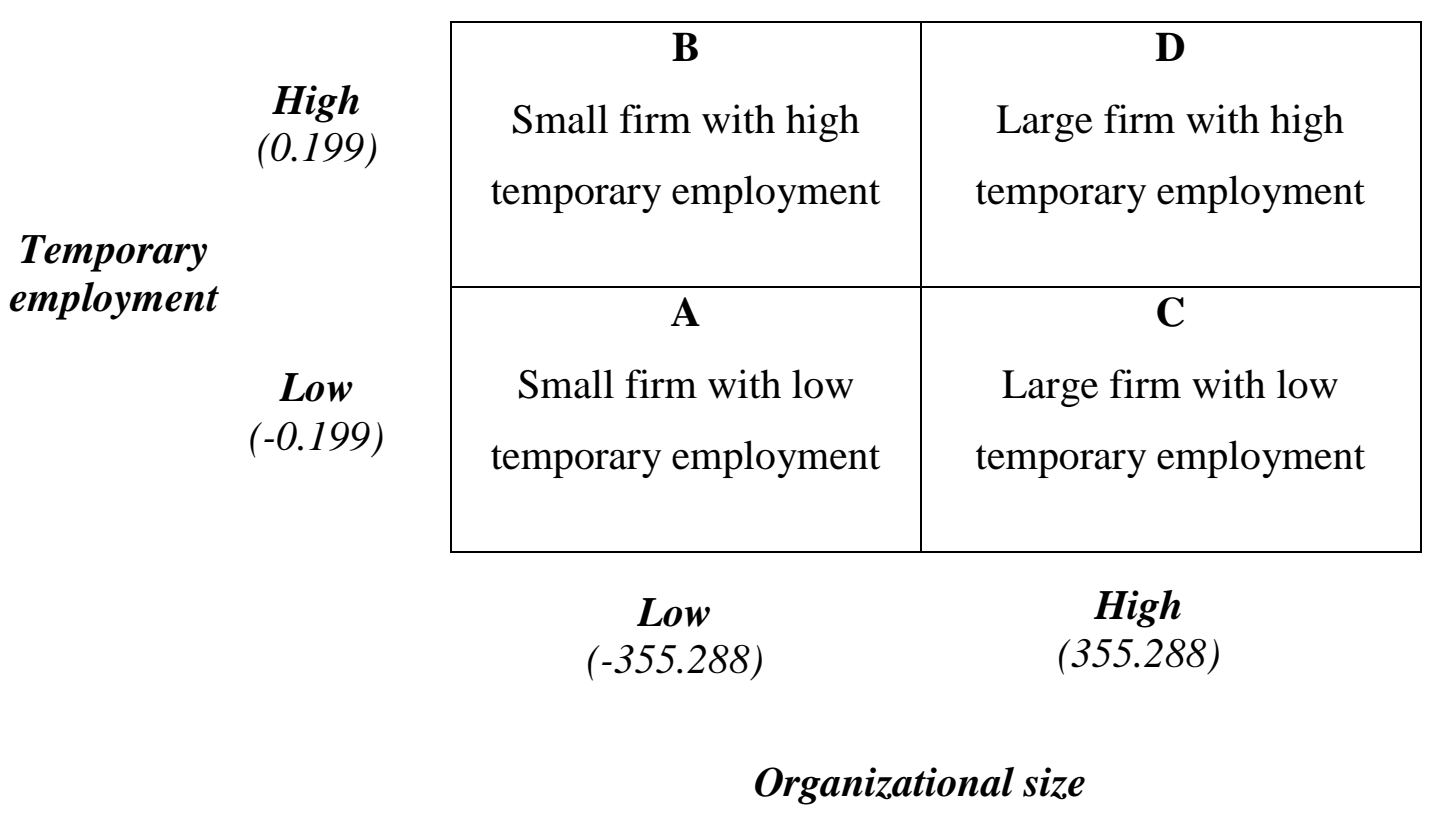


Figure 2. Effect of human capital on labor productivity according to temporary employment and organizational size

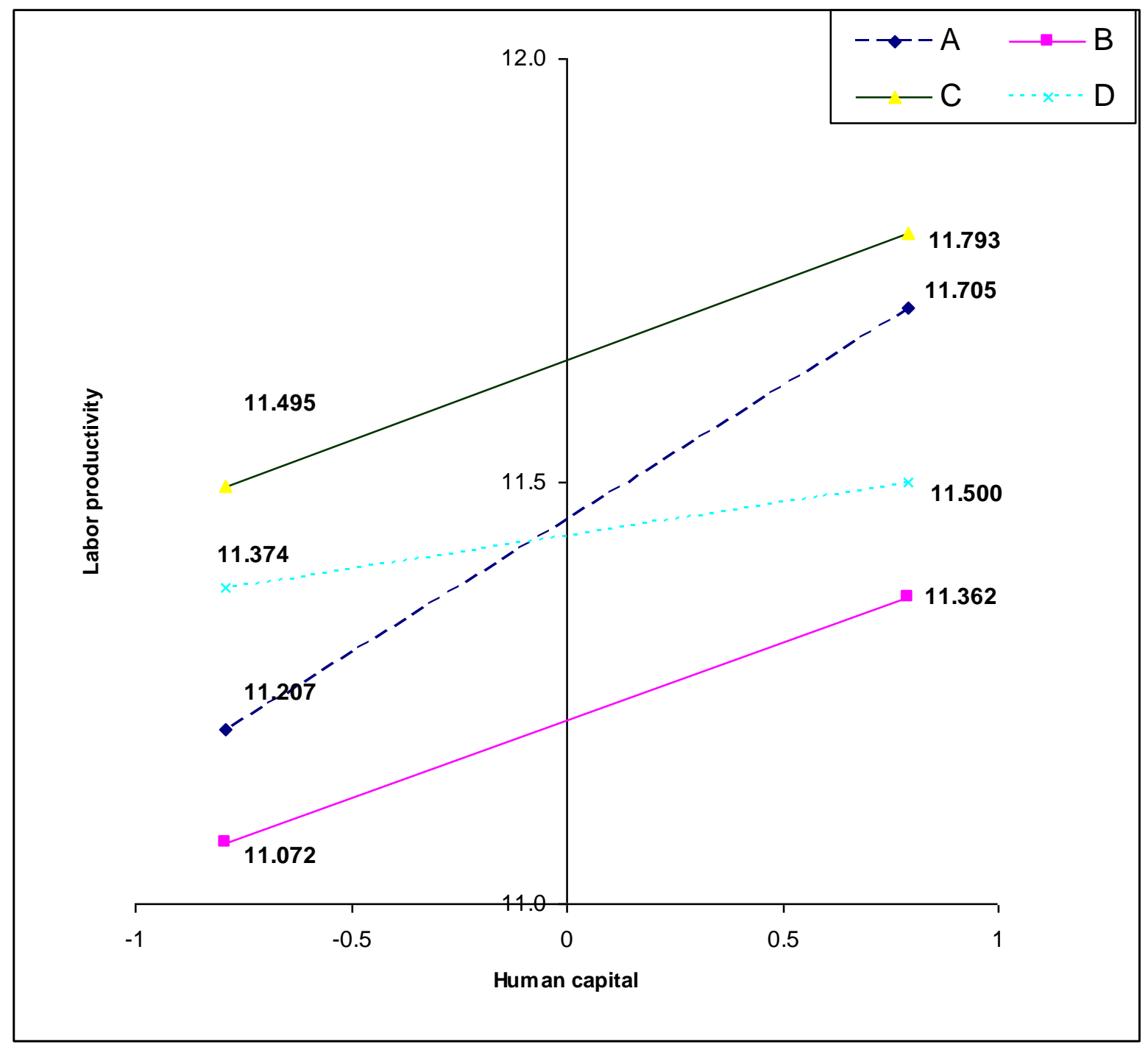


Figure 3. Effect of human capital on return on sales according to temporary employment and organizational size

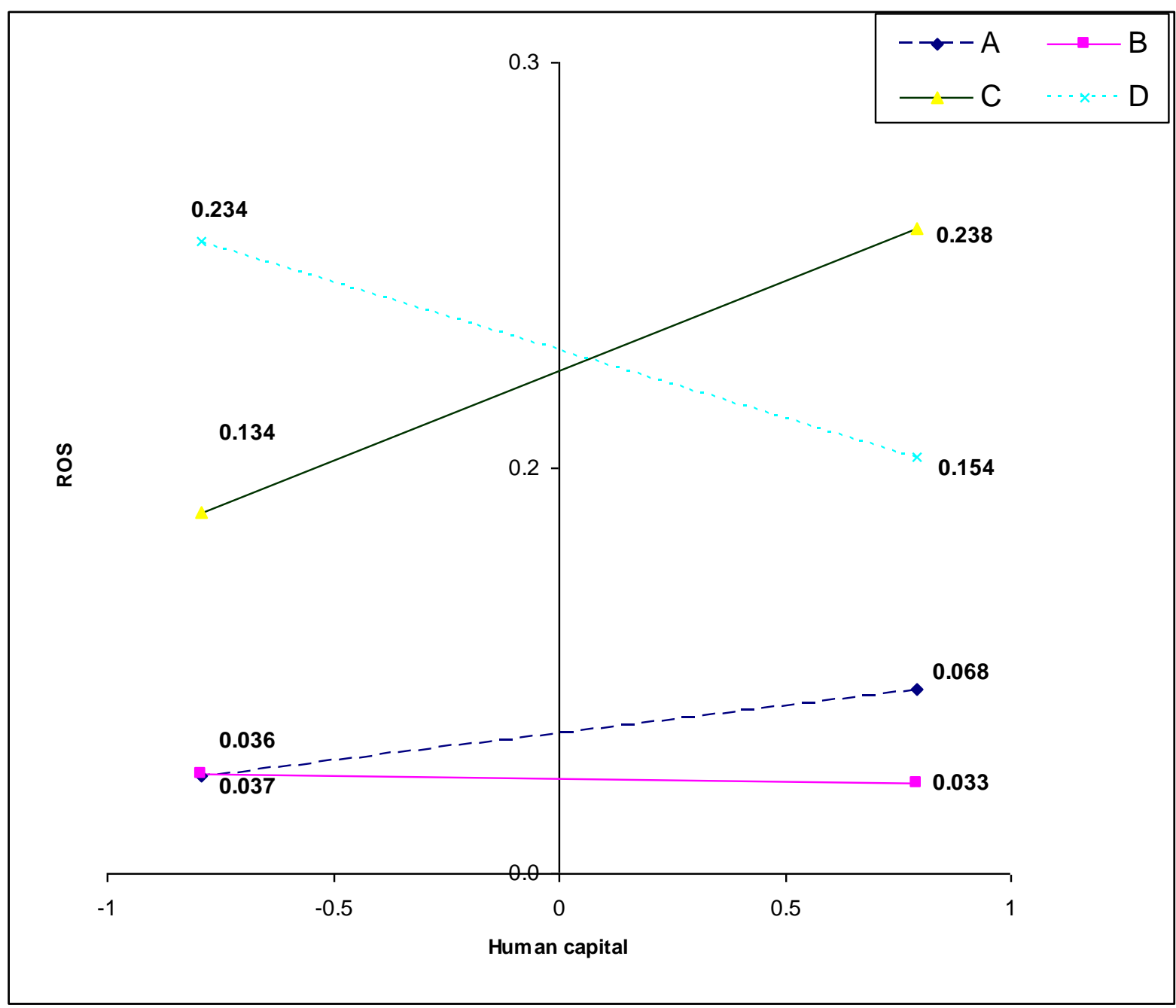

